\author{
Quarterly Journal of Econometrics Research \\ 2021 Vol. 7, No. 1, pp. 13-30. \\ $\operatorname{ISSN}(e): 2411-0523$ \\ $\operatorname{ISSN}(p): 2518-2536$ \\ DOI: 10.18488 /journal.88.2021.71.13.30 \\ (C) 2021 Conscientia Beam. All Rights Reserved. \\ check for
updates
}

\title{
ECONOMETRIC ANALYSIS OF DUTCH DISEASE IMPLICATION OF CHINA-AFRICA TRADE
}

Tirimisiyu F.
Oloko $^{1+}$
(D) Muritala O.
Ogunsiji $^{2}$
iD Musefiu A.
Adeleke $^{3}$

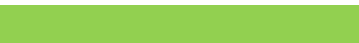

Article History

Received: 22 June 2021

Revised: 26 July 2021

Accepted: 18 August 2021

Published: 13 September 2021

\section{Keywords}

China-Africa trade Dutch disease Dynamic GMM models Manufacturing secto Agricultural sector Africa.

JEL Classification: C23; F14; Q32; Q37.

\author{
${ }^{\prime}$ Centre for Econometric and Allied Research, University of Ibadan, Ibadan, \\ Nigeria; Department of Economics, University of Ibadan, Ibadan, Nigeria. \\ Email:olokotrimicy@yahoo.com Tel: +2347088955676 \\ ${ }^{2}$ Department of Economics, Fountain University, Osogbo, Nigeria. \\ Email: murtadaogunsiji@gmail.com Tel: +2348154830430 \\ ${ }^{s}$ Department of Economics, University of Ibadan, Ibadan, Nigeria. \\ Email:adelekemusefiu@gmail.com Tel: +2348028999777
}

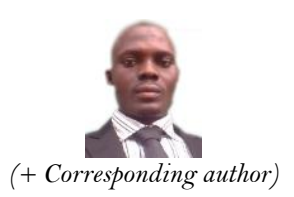

ABSTRACT

This study revisits the analysis of the Dutch disease implication of China-Africa trade for Africa's non-mineral resources sectors; specifically, manufacturing and agricultural sectors, while focusing on the trade relationship between China and 27 African countries for the period of 19years, 2001 to 2019. This prompted an econometric analysis with the use of two-step dynamic (difference and system) panel Generalized Method of Moment (GMM) models, which was also complemented with dynamic least squares panel econometric regression. The preliminary analysis revealed that Ethiopia is the largest African trading partner with China, with an average of about 21 percent China-Ethiopia trade ratio, while Botswana has the least trade relation with China, with 1.5percent Botswana-China trade ratio. The result of our econometric analyses suggests that higher China-Africa trade has the potential to reduce Africa's manufacturing value-added. In other words, China-Africa trade is not causing Dutch disease in Africa but has the potential to cause Dutch disease in the future. Furthermore, the result suggests that higher China-Africa trade has the potential to increase Africa's agricultural sector productivity. This implies that China-Africa trade has no tendency of causing Dutch disease in the agricultural sector. Our results are robust to different data structures for the dynamic GMM model.

Contribution/Originality: This study is one of the very few studies which have investigated the Dutch disease implication of China-Africa trade for African countries. It focused on sectoral growth rather than the aggregate growth of the economy and also employed two-step dynamic (difference and system) panel Generalized Method of Moment (GMM) models.

\section{INTRODUCTION}

There is a growing literature on the analysis of the trade relationship between China and Africa, but the results have been mixed and inconclusive (Ado \& Su, 2016). The trade pattern between Africa and China has been motivated by the endowment-based Heckscher-Ohlin trade theory, as Africa exports its abundant natural resources to, and imports industrial and manufactured goods from China (Eisenman, 2012; Mlambo, Kushamba, \& Simawu, 2016). While some studies have suggested that China-Africa trade may reinforce Africa's resources dependence and cause de-industrialization of the region (Ado \& Su, 2016; Geda, Mosisa, \& Assefa, 2013; Martuscelli, 2018) others pointed out that the trade pattern between China and Africa would be more beneficial to Africa's growth and development if handled with great care, as it tends to bridge the current infrastructure gap and generate funds 
needed to facilitate diversification into the other sectors of the economy (Asongu \& Aminkeng, 2013; Habiyaremye, 2016; He, 2013).

Many African nations have been identified to suffer from the Dutch disease syndrome - a situation where the booming resource sector crowds out the manufacturing sector (Apergis, El-Montasser, Sekyere, Ajmi, \& Gupta, 2014; Barczikay, Biedermann, \& Szalai, 2020). The potential of the China-Africa trade to cause Africa to be in a perpetual state of de-industrialization indicates that China-Africa trade may be another causal factor for Dutch disease in Africa (Geda et al., 2013; Martuscelli, 2018). Conventionally, China-Africa trade will have no Dutch disease implication if it does not crowd out the manufacturing sector or cause de-industrialization in Africa. As many African countries are working towards diversifying their economies from being a natural resource-based (Barczikay et al., 2020) this study is very significant as it tends to analyze the causes of drags in the growth of nonmineral resources sectors, particularly by examining the effect of China-Africa trade on the growth of the manufacturing and agricultural sectors in Africa.

Previous studies on China-Africa trade have highlighted the implication of the trade relation for Africa from different fronts including economic growth, environment, governance, geographical trade diversification, and industrialization; to which the current study aligns. An extensive review by Ado and Su (2016) of the relevant papers on Shino-African trade between 2001 and 2011 revealed that the win-win argument of the Sino-African trade relation is inconclusive, particularly in its effect on industrialization. The protagonists of China-Africa trade's implication for Africa include; He (2013); De Grauwe, Houssa, and Piccillo (2012); Habiyaremye (2016). He (2013) noted that China's increasing trade with Africa is helpful to African economic development. De Grauwe et al. (2012) noted that Africa has achieved trade expansion and geographical trade diversification by trading with China, as against some developed countries which reject trading with Africa due to low governance standing. This view was also supported by Martuscelli (2018) which found that China-Africa trade has a positive growth effect on Africa. Habiyaremye (2016) noted that China-Africa trade reduces existing infrastructure bottlenecks and so, helps to increase the diversification capacity of Africa. Also, Maswana (2009) observed that Africa might benefit from China's growth through technology-embodied capital goods imports; and Tawiah, Zakari, and Khan (2020) found a negative relationship between importation from China and carbon emissions, implying a positive environmental footprint by China in Africa.

Meanwhile, some protagonists of the China-Africa trade relation also expressed some caution, particularly as regards trade's implication for industrialization in Africa. For instance, Habiyaremye (2016) noted that the abundance of natural resources tends to hamper export diversification by crowding out other tradable resources. Similarly, Martuscelli (2018) observed that Chinese competition may hamper Africa's manufacturing growth while the increasing natural resource specialization of African countries poses a danger to diversification, structural transformation, and future growth prospects. The results from Maswana (2009) also downplayed the importance of the export-led growth hypothesis, suggesting that the export of natural resources to China does not enhance Africa's growth. Other studies with mixed results include; Asongu and Aminkeng (2013) and Taivan, Nene, and Boubacar (2015). Asongu and Aminkeng (2013) revealed that China-Africa trade is beneficial to Africa in the short run but may have negative economic effect in the long run, while Taivan et al. (2015) noted that the effect of commodity export to China by Africa is statistically significant but not large enough to induce positive growth rates.

The antagonists of the China-Africa trade include Maswana (2009); Peh and Eyal (2010); Davies, Draper, and Edinger (2014) and Huang et al. (2017). The results from Maswana (2009) seemingly downplay the importance of the export-led growth hypothesis, which implies that export to China does not promote Africa's growth. Peh and Eyal (2010) suggest that China's increasing interest in the exploitation of African natural resources may result in more harm than good for the African environment. Similarly, Davies et al. (2014) state that China's policy to provide economic and technological aids in exchange for natural resources from Africa undermines African 
industry. The findings by Huang et al. (2017) suggests that China-Africa trade may contribute to heavier pollution in China and retard the development of local industry in Africa, while Geda et al. (2013) hinted that Africa's state of industrialization could become precarious if the current pattern of trade specialization between the two regions remains unchanged.

The main objective of this study is to investigate the existence of Dutch disease implications of China-Africa trade for Africa. This will specifically be achieved by examining the effect of China-Africa trade on the growth of Africa's manufacturing and agricultural sectors. Empirical evidence has shown that the achievement of economic diversification by resource-rich countries has been very difficult (Alsharif, Bhattacharyya, \& Intartaglia, 2017; Barczikay et al., 2020; Kireyev, 2021). Thus, an investigation into the causes of drags in the growth of Africa's manufacturing and agricultural sectors as proposed by this study is important. Our study is distinctively different from studies on the economic growth effect of China-Africa trade such as Maswana (2009) and Taivan et al. (2015) as it focuses on sectoral growth of the economy rather than the aggregate growth of the economy. It is, however, similar to the study by He (2013) which assessed the impacts of imports from China on Sub-Saharan African manufactured exports. Using random-effects and the Generalized two-stage least squares random-effects IV (G2SLS-RE-IV) models, He (2013) revealed that Chinese impacts are significantly positive in all sectors. This result suggests that the China-Africa trade has no Dutch disease implication on Africa. Martuscelli (2018) however, holds a converse position as it tends to support the existence of Dutch disease implication of China-Africa trade on Africa.

Thus, this study revisits the analysis of the implication of China-Africa trade for Africa's non-mineral resources sectors. It contributes to the literature on China-Africa trade analysis in two distinct ways. First, it examines the effect of China-Africa trade on the non-mineral resources sectors' performance. The performance of the non-mineral sectors of the economy is measured as the value added by the sectors relative to the total GDP (Apergis et al., 2014; Matallah, 2020) as against export-based indicators used by related studies such as He (2013) and Habiyaremye (2016). Our choice indicator appears more representative as a measure of sectoral performance, as export indicators [such as sectoral export (as in He (2013)) and export diversification index (as in Habiyaremye (2016)] do not capture improvement in the productive capacity within the absorptive level. This tends to underestimate the performance of the sector. Also, rather than focusing only on the manufacturing sector, analysis of the Dutch disease implication of the China-Africa trade was extended to Africa's agricultural sector. The consideration of the agricultural sector was justified based on the study by Apergis et al. (2014) which found evidence of a Dutch disease effect of an oil sector boom on agriculture in the MENA countries.

The second contribution of the study to the literature is in the area of methodology. Specifically, this study employs the two-step dynamic (difference and system) Generalized Method of Moments (GMM) by Arellano and Bond (1991) and Blundell and Bond (1998). This method is similar to the G2SLS-RE-IV used in a related study by $\mathrm{He}(2013)$ as it is also an instrumental variable-based model. However, this method is found to be more efficient in dealing with short panels; where there is an asymptotic of large $\boldsymbol{N}$ and small $\boldsymbol{T}$ - which is the case in this study (Blackburne \& Frank, 2007). The significance of the two-step dynamic GMM model in dealing with endogeneity and heterogeneity issues has been well appreciated in studies on Dutch disease analysis (see (Apergis et al., 2014; Habiyaremye, 2016; Matallah, 2020)) albeit not on Dutch disease analysis of China-Africa trade on African countries. This study fills an important gap in the literature as it sets to be the first study on the effect of ChinaAfrica trade on African sectoral performance to employ dynamic (difference and system) Generalized Method of Moments (GMM) models.

The remaining sections of this study are organized as follows. Section 2 presents the stylized facts on ChinaAfrica trade and Africa's non-mineral resources sectors productivity. Section 3 discusses the econometric framework for the Generalized Method of Moments (GMM) model employed in this study. The presentation and discussion of the preliminary and empirical results are detailed in Section 4, while Section 5 concludes the study. 


\subsection{Stylized Facts on China-Africa Trade and Africa's Non-Mineral Resources Sectors Productivity}

The China-Africa relation dates back to 1956 but the relationship has improved tremendously during the $2000 \mathrm{~s}$ (Mlambo et al., 2016; Taivan et al., 2015). The trade relationship between China and Africa between 2001 and 2019 is reviewed in Figure 1. The figure consists of China's import from Africa (which is Africa's export to China), China's export to Africa (which is Africa's import from China), and Africa's trade balance, which is the difference between Africa's export to, and import from, China. As evident from the figure, the persistent increase in ChinaAfrica trade from 2001 was truncated in 2009 possibly due to the fall in crude oil price in 2009 as a result of the 2007/2008 Global Economic and Financial Crisis. The trade between China and Africa was fairly balanced before 2009 as evident from Africa's trade balance graph which is fairly zero along the period axis. Specifically, China's export to Africa increased from US $\$ 5.96$ billion in 2001 to US $\$ 51.1$ billion in 2008 , while Africa’s export to China increased from US $\$ 4.79$ billion in 2001 to US\$55.97 billion in 2008. More so, while China-Africa trade was on the rising trend between 2010 and 2014, Africa recorded a positive trade balance with China ranging from the minimum of US\$7.25 billion in 2012 to the maximum of US\$28.1 billion in 2012.

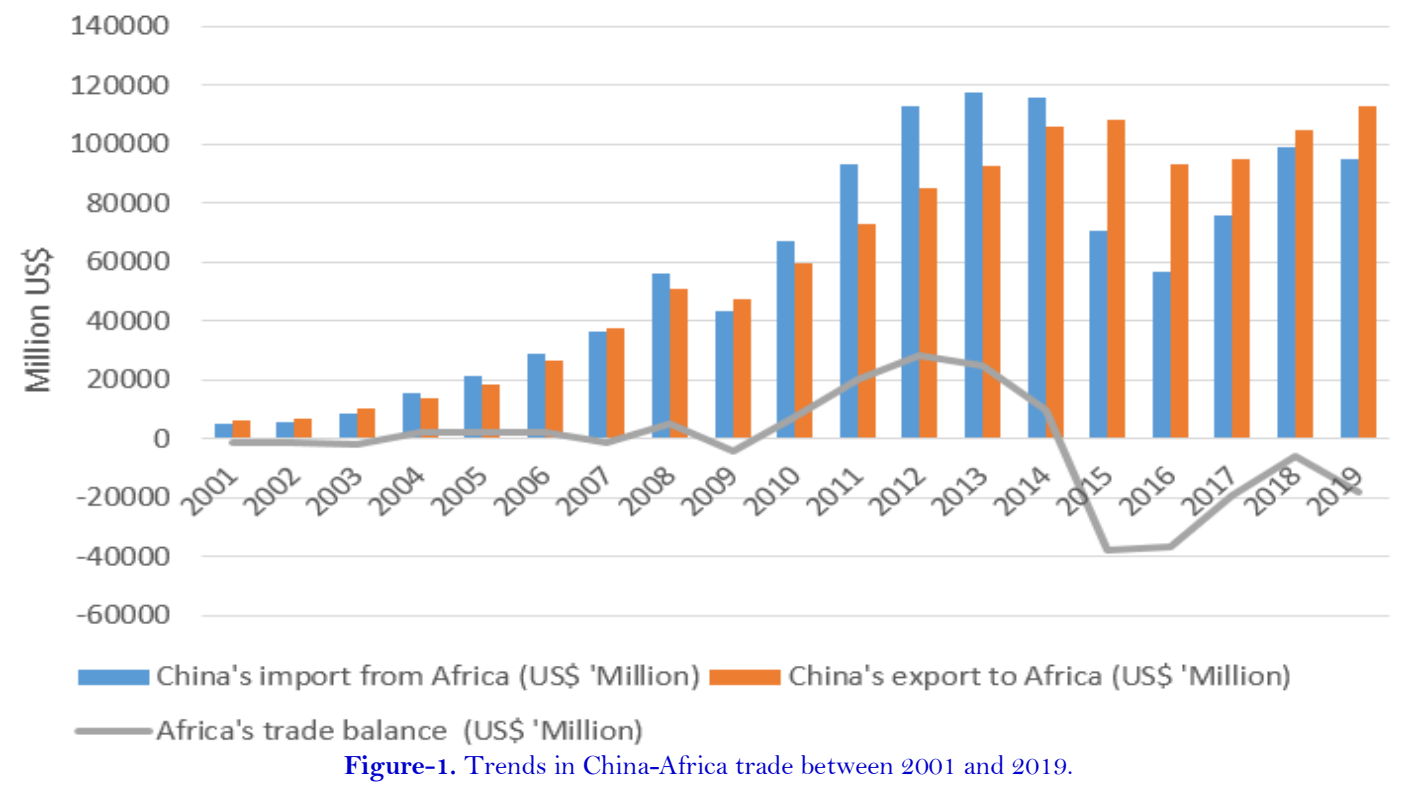

In the recent five years between 2015 and 2019, Africa recorded a negative trade balance with China, with the largest negative trade balance being US\$38.05 billion recorded in 2015 and the least negative trade balance being US $\$ 5.93$ billion recorded in 2018. The fall in Africa's export to China from 2014 through 2016 may not be unassociated with the fall in crude oil price, which is one of the major natural resources traded by Africa with China $^{1}$. As evident from Table 1, which shows the list of top 10 commodities exported by Africa to China (as a percentage of total exports), mineral resources including crude oil contribute between 63 and 72 percent of total Africa's export to China between 2001 and 2013. It only dropped to about 55 to 50 percent in recent years between 2017 and 2019 due to an increase in the contribution of other natural resources such as precious stones and metals from 4.78 percent in 2013 to 7.7 percent in 2017 and 13.52 percent in 2019 . The contribution of Ore, slag and ash to total Africa's export to China also increased from 11.77 percent in 2013 to 17.25 percent in 2019.

Table 1 shows that the top 10 commodities exported to China by African countries are predominantly natural resources which suggest that Africa can truly become over-dependent on natural resources. The contribution of the top 10 commodities exported by African countries to China is high (above 90 percent) and increasing (as it increased from 91.63 percent in 2001 to 95.47 percent in 2019). This suggests that there is a rising concentration of

${ }^{1}$ See: https://www.tralac.org/resources/infographic/12706-china-s-trade-with-africa-2016-update.html. 
African countries in the mineral resources sector indicating the potential for the region to suffer from Dutch disease due to its trade relationship with China. Earlier studies on the China-Africa trade have indicated that China's trade with Africa is fascinated with the presence of natural resources in Africa (which serves as raw materials to fuel China's growth) and the opportunity of a new export market (De Grauwe et al., 2012).

Table-1. Top 10 commodities exported by Africa to China (Percentage of total exports).

\begin{tabular}{l|c|c|c|c|c|c|c}
\hline Items & $\mathbf{2 0 0 1}$ & $\mathbf{2 0 0 5}$ & $\mathbf{2 0 0 9}$ & $\mathbf{2 0 1 3}$ & $\mathbf{2 0 1 7}$ & $\mathbf{2 0 1 9}$ \\
\hline $\begin{array}{l}\text { Mineral fuels, mineral oils and products of their } \\
\text { distillation; bituminous substances; mineral ... + }\end{array}$ & 62.95 & 71.63 & 66.45 & 72.16 & 54.89 & 50.41 \\
\begin{tabular}{l} 
Commodities not elsewhere specified \\
\hline Ores, slag and ash
\end{tabular} & 9.06 & 7.49 & 14.10 & 11.77 & 17.23 & 17.25 \\
\hline $\begin{array}{l}\text { Natural or cultured pearls, precious or semi-precious } \\
\text { stones, precious metals, metals clad ... }\end{array}$ & 2.87 & 4.58 & 4.15 & 4.78 & 7.70 & 13.52 \\
\hline Copper and articles thereof & 1.46 & 1.54 & 3.77 & 3.78 & 5.18 & 5.80 \\
\hline Other base metals; cermets; articles thereof & 0.85 & 0.23 & 0.60 & 0.49 & 2.62 & 2.02 \\
\hline Wood and articles of wood; wood charcoal & 8.14 & 2.51 & 1.83 & 1.32 & 2.96 & 1.94 \\
\hline Iron and steel & 2.07 & 2.26 & 2.41 & 0.92 & 2.30 & 1.74 \\
\hline $\begin{array}{l}\text { Oilseeds and oleaginous fruits; miscellaneous grains, } \\
\text { seeds and fruit; industrial or medicinal ... }\end{array}$ & 0.01 & 0.52 & 0.76 & 0.65 & 1.10 & 1.57 \\
\hline Tobacco and manufactured tobacco substitutes & 2.26 & 0.62 & 0.33 & 0.52 & 0.89 & 0.68 \\
\hline Edible fruit and nuts; peel of citrus fruit or melons & 0.01 & 0.06 & 0.04 & 0.09 & 0.46 & 0.55 \\
\hline Top 10 Commodities & 91.63 & 94.95 & 94.85 & 96.65 & 94.88 & 95.47 \\
\hline
\end{tabular}

Table-2. Top 10 commodities imported by Africa from China (Percentage of total imports).

\begin{tabular}{|c|c|c|c|c|c|c|}
\hline Items & 2001 & 2005 & 2009 & 2013 & 2017 & 2019 \\
\hline $\begin{array}{l}\text { Electrical machinery and equipment and parts thereof; } \\
\text { sound recorders and reproducers, television ... }\end{array}$ & 12.68 & 15.02 & 16.32 & 13.21 & 14.86 & 14.54 \\
\hline $\begin{array}{l}\text { Machinery, mechanical appliances, nuclear reactors, } \\
\text { boilers; parts thereof }\end{array}$ & 8.53 & 11.48 & 13.47 & 12.57 & 11.75 & 11.79 \\
\hline $\begin{array}{l}\text { Vehicles other than railway or tramway rolling stock, and } \\
\text { parts and accessories thereof }\end{array}$ & 4.34 & 7.77 & 7.91 & 7.29 & 5.59 & 5.89 \\
\hline Articles of iron or steel & 3.68 & 4.84 & 7.22 & 5.05 & 4.82 & 5.26 \\
\hline Plastics and articles thereof & 1.82 & 2.36 & 2.44 & 3.67 & 3.94 & 4.23 \\
\hline $\begin{array}{l}\text { Furniture; bedding, mattresses, mattress supports, } \\
\text { cushions and similar stuffed furnishings; ... }\end{array}$ & 1.24 & 1.70 & 2.36 & 4.37 & 3.43 & 3.47 \\
\hline Footwear, gaiters and the like; parts of such articles & 5.51 & 4.14 & 3.01 & 3.72 & 3.80 & 3.29 \\
\hline $\begin{array}{l}\text { Articles of apparel and clothing accessories, not knitted or } \\
\text { crocheted }\end{array}$ & 3.97 & 4.32 & 2.34 & 2.26 & 3.31 & 3.17 \\
\hline $\begin{array}{l}\text { Man-made filaments; strip and the like of man-made } \\
\text { textile materials }\end{array}$ & 2.67 & 3.20 & 1.91 & 2.02 & 2.56 & 3.12 \\
\hline Iron and steel & 0.42 & 0.74 & 1.66 & 2.56 & 3.07 & 3.08 \\
\hline Top 10 commodities & 57.13 & 63.31 & 63.78 & 60.16 & 59.11 & 57.84 \\
\hline
\end{tabular}

Table 2 presents the list of the top 10 commodities imported by African countries from China. Evidently, this is dominated by manufactured goods with the topmost being electrical machinery and equipment, sound recorders and reproducers, television, and others. The contribution of these goods to total imports from China has increased from 12.68 percent in 2001 to 14.54 percent in 2019. Other manufactured goods imported by Africa from China are; the machinery, mechanical appliances, nuclear reactors, boilers; parts thereof, whose contribution to total Africa's import from China ranges from 8.53 percent in 2001 to 13.47 percent in 2009; vehicles other than railway or tramway rolling stock, and parts and accessories thereof, whose contribution ranges from 4.34 percent in 2001 to 7.91 percent in 2009; and Plastics and articles thereof, whose contribution to China's goods imports has increased from 1.82 percent in 2001 to 4.23 percent in 2019. Unlike Africa, the contribution of the top 10 commodities export by China to Africa ranges from 57.13 percent in 2001 to 63.78 percent in 2009, suggesting that China's economy is well diversified. Earlier studies have noted that Africa's trade with China is motivated by the low-cost bidding 
strategy of China due to China's comparative advantage in labour-intensive and capital-intensive production (Eisenman, 2012; Nowak, 2016). Another cause is the economic diplomacy and development assistance offered by China to its trading partners. This is apparent as China offers low-interest-rate loans to its trading partners without interfering in their domestic affairs unlike the West (Mlambo et al., 2016; Nowak, 2016).

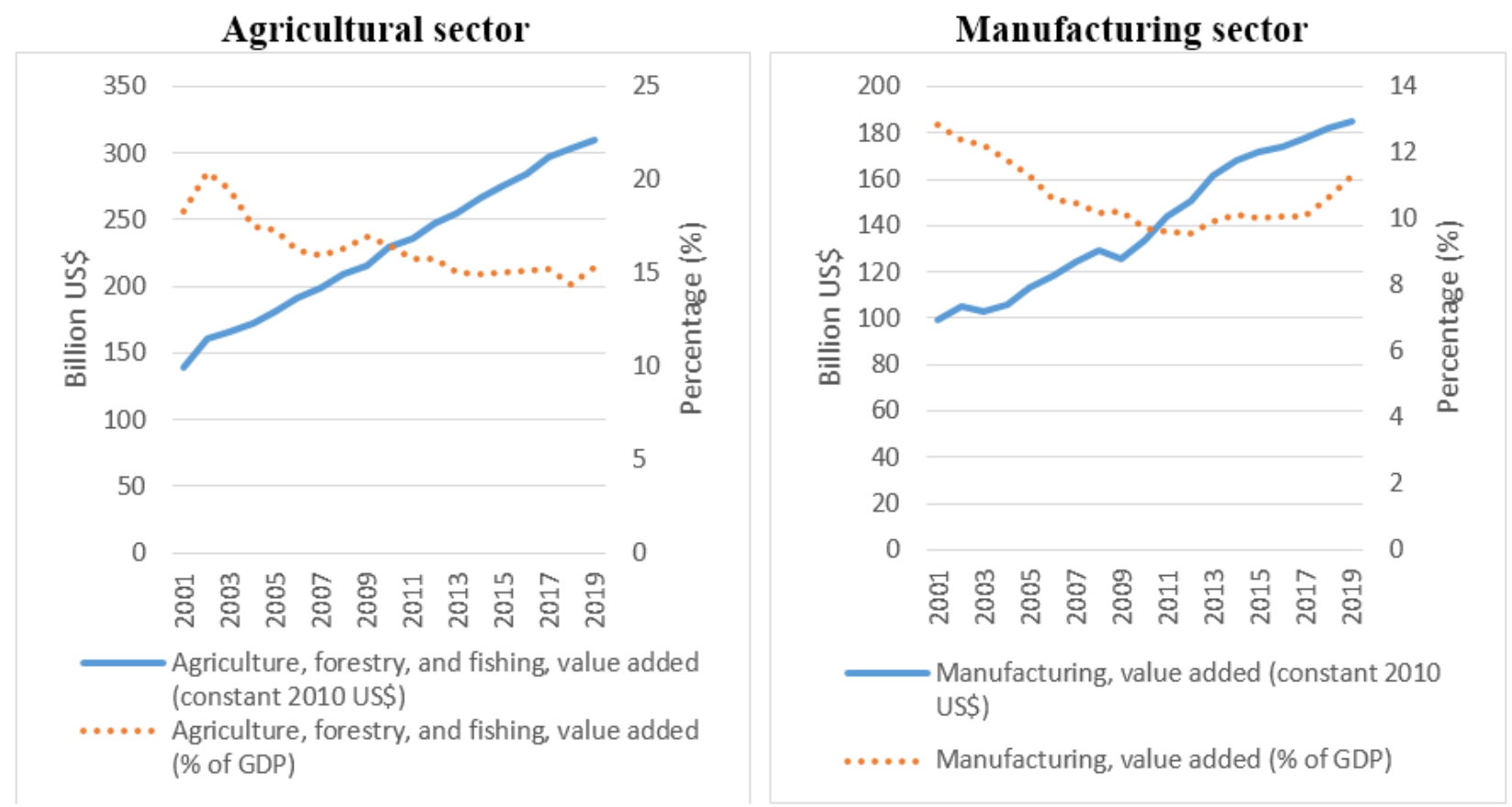

Figure-2. Sectoral value added of the SSA countries between 2001 and 2019.

The trend in sub-Saharan Africa's manufacturing and agricultural sectors performance over the 2001 and 2019 period is presented in Figure 2. This was represented by the value added by these non-mineral resources sectors and their relative percentage to $\mathrm{GDP}^{2}$. As evident from the figure, the value-added by the agricultural sector increased by more than 100 percent from US $\$ 139.2$ billion in 2001 to US $\$ 310.1$ billion in 2019 , while the valueadded by the manufacturing sector increased by about 86 percent from US $\$ 98.97$ billion in 2001 to US $\$ 184.8$ billion in 2019. Meanwhile, the contribution of these sectors to GDP has been declining. Specifically, the agriculture valueadded (as \% of GDP) declined from 20.4 percent in 2002 to 14.38 percent in 2018, while the manufacturing valueadded (as \% of GDP) declined on average, from 12.84 percent in 2001 to 11.33 percent in 2019; having declined deeply to 9.54 percent in 2012. This suggests that African countries may be suffering from Dutch disease. This study proposes to conduct an empirical analysis to examine whether China-Africa trade has Dutch disease implications or contributes to the slow growth of the manufacturing and agricultural sectors in Africa.

\section{MODEL AND METHODOLOGY}

In this study, we acknowledge the significance of initial stocks or past developments within the sector as one of the main determinants of the current performance of Africa's manufacturing and agricultural sectors. This follows the approach in some of the recent studies on economic and sectoral growth (see (Rashid et al., 2019a; Rashid et al., 2019b; Sung, Song, \& Park, 2018)). Hence, we rely on dynamic panel data regression methods of analysis using specifically, the two-step difference Generalized Method of Moment (diff-GMM) approach by Arellano and Bond

\footnotetext{
2 Agriculture corresponds to ISIC divisions 1-5 and includes forestry, hunting, and fishing, as well as cultivation of crops and livestock production. Manufacturing refers to industries belonging to ISIC divisions 15-37. Value added is the net output of a sector after adding up all outputs and subtracting intermediate inputs. It is calculated without making deductions for depreciation of fabricated assets or depletion and degradation of natural resources. The origin of value added is determined by the International Standard Industrial Classification (ISIC), revision 3 or 4.
} 
(1991) and the two-step system Generalized Method of Moment (sys-GMM) method by Blundell and Bond (1998). More importantly, these two methods are suitable for the asymptotic of large $\mathrm{N}$ and small $\mathrm{T}$ (or $\mathrm{N}>\mathrm{T}$ ) dynamic panel (Blackburne \& Frank, 2007) which is the case in our study; where we are dealing with 27 African countries over 19 years (2001 to 2019).

The main objective of this study is to examine the effect of China-Africa trade on the manufacturing and agricultural sectors' performance in Africa which helps to assess whether the trading relationship has a Dutch disease effect on Africa. We rely on the basic Solow growth model, where economic growth is defined as a function of labour and capital. Thus, we specify the growth of Africa's manufacturing and agricultural sectors, basically, as a function of employment in these sectors and the capital infrastructure available in the economy. This model is then augmented with China-Africa trade and other control variables. Specifically, the dynamic models of the two sectors are specified as follows:

$$
\begin{aligned}
& \operatorname{lman}_{i t}=\alpha_{i} \operatorname{lman}_{i t-1}+\beta_{i 1} \text { lempman }_{i t}+\beta_{i 2} \text { linf }_{i t}+\beta_{i 3} \text { lchnafrtrade }_{i t}+Z_{i t}^{\prime} \beta+\phi_{i}+\varepsilon_{i t} \\
& \operatorname{lagr}_{i t}=\alpha_{i} \text { lagr }_{i t-1}+\beta_{i 1} \text { lempagr }_{i t}+\beta_{i 2} \text { linf } r_{i t}+\beta_{i 3} \text { lchnafrtrade }_{i t}+Z_{i t}^{\prime} \beta+\phi_{i}+\varepsilon_{i t}
\end{aligned}
$$

where lman and lempman in Equation 1a indicate log of manufacturing value added (\% of GDP) and log of employment in the manufacturing sector (\% of total employment), respectively; and, lagr and lempagr in Equation $1 \mathrm{~b}$ indicate log of agriculture value added (\% of GDP) and log of employment in the agricultural sector (\% of total employment), respectively. Whereas, $l$ inf $r$ is the $\log$ of infrastructural facilities, measured as infrastructure index consisting of transportation, electricity, and ICT infrastructure in Africa; while lchnafrtrade is the $\log$ of the bilateral trade between Africa and China relative to the bilateral trade of Africa with the world. This is computed as the addition of Africa's import from and export to China, divided by Africa's import from and export to the world.

The $Z_{i t}^{\prime}$ indicates other variables considered. These include; exchange rate (lexr $)$ represented by the price of a unit of US\$ in a local currency such that an increase implies depreciation and a decrease implies appreciation; income $(\lg d p)$ measured as the GDP per capita (constant 2010 US\$); and trade openness (1top) measured as trade (\% of GDP). All variables are logged to facilitate easy interpretation. The data for all variables are obtained from World Development Indicators (WDI) database, except the infrastructure index or Africa Infrastructure Development Index (AIDI), obtained from the African Development Bank database.

As the dynamic model contains the lag of the dependent variable as an explanatory variable, there is an inherent problem of autocorrelation and endogeneity which makes the results from the OLS, fixed effect (FE) and Generalized Least Square GLS method, random effect (RE) to be biased and inconsistent (Baltagi, 2008) ${ }^{3}$. These problems are corrected by Arellano and Bond GMM estimator as it differences the dynamic model to eliminate the autocorrelation and endogeneity effects along with any time-invariant regressor such as the constant term. This is why it is referred to as the Difference GMM dynamic panel data model.

The Blundell and Bond GMM estimator considers resolving the problem of autocorrelation and endogeneity in the dynamic model without losing the level specification of the model. This results in having both level and first

\footnotetext{
${ }^{3}$ In this study, however, we also estimate the dynamic model with these conventional methods to evaluate the consistency of our result, particularly as regards the sign and significance.
} 
difference models which are estimated in a system; hence is it called system GMM estimator. The system GMM estimator uses lagged differences of the dependent variable as an instrument for equations at levels, in addition to lagged levels of the dependent variable as instruments for equations in the first difference (Baltagi, 2008).

For both difference and system GMM estimators to be valid for estimation, we expect to reject the null hypothesis for the $\operatorname{AR}(1)$ test while we do not reject the null for $\operatorname{AR}(2)$. Besides, the null hypothesis on the validity of the instrument using Hansen's and Sargan's tests is not expected to be rejected. We have one-step and two-step versions of both difference and system GMM, this study sticks to the use of a two-step estimator as it is expected to perform better than the one-step method when there is evidence of heteroscedasticity in the remainder disturbances, and perform as good as one-step method when the remainder errors are homoscedastic (Olubusoye, Salisu, \& Olofin, 2016).

\section{ANALYSIS OF RESULTS}

This section contains three sub-sections. The first deals with the descriptive analysis, where the summary statistics of the variables in the model are discussed. The second sub-section contains the main empirical analysis of this study. This is the presentation and discussion of the empirical results of this study. The third sub-section deals with robustness for evaluation of the consistency of the result of this study in the face of alternative model specification. In this study, we use 3-year average data for robustness. This makes our time, T to reduce from 19 to 7 , while countries remain 27 .

\subsection{Descriptive Analysis}

Table 3 presents country-specific descriptive statistics for the main variables; China-Africa trade (as a percentage of total trade), manufacturing value-added (\% of GDP) and agriculture value-added (\% of GDP). As evident from the table, Ethiopia is the largest African trading partner with China, with an average of about 21 percent China-Ethiopia trade ratio between 2001 and 2019. Other top African trading partners with China include Benin Republic, Mauritania, Nigeria, Togo, South Africa, and Cameroon which have 13.7 percent, 13.1 percent, 12.7 percent, 10.7 percent, 10.6 percent, and 10.6 percent trade ratio with China, respectively. Botswana was observed to have the least trade relation with China, with an average Botswana-China trade ratio of about 1.5 percent. Other African countries with relatively low trade relations with China include Namibia, Eswatini, Tunisia, Zimbabwe, and Morocco, with 2.1 percent, 2.6 percent, 3.5 percent, 3.8 percent, and 4.8 percent trade ratio with China, respectively. From the table, it can be noted that five top African trade partners with China are from West Africa, except for Ethiopia, which is an East African country. This may suggest that West Africa trades more with China than any other region in Africa. Conversely, the five least African trade partners with China are spread between North Africa and Southern Africa, except for Zimbabwe which is an East African country.

Furthermore, the table shows that Algeria has the largest growing manufacturing sector in Africa, with the manufacturing value-added to GDP ratio of about 35.4 percent. This is followed by Eswatini, which also has a very high manufacturing value-added to GDP ratio of about 32.1 percent. Evidently, these two countries with a fastgrowing manufacturing sector in Africa have a low trade ratio with China, which is approximately 6.5 percent for Algeria and 2.6 percent for Eswatini. This may suggest a negative relationship between China-Africa trade and manufacturing sector growth in Africa, and the possible presence of Dutch disease. This argument is further supported by evidence from African countries that are top trading partners with China; such as Ethiopia, Nigeria, and Mauritania. These countries are noted to have low manufacturing value-added to GDP ratio; with an average of 4.9 percent, 9.7 percent, and 8 percent, respectively. 
Table-3. Country-Specific Descriptive Statistics for the Main Variables.

\begin{tabular}{|c|c|c|c|c|c|c|c|c|c|c|c|c|}
\hline \multirow[b]{2}{*}{ Country } & \multicolumn{4}{|c|}{$\begin{array}{l}\text { China-Africa Trade } \\
\text { (\% of total trade) }\end{array}$} & \multicolumn{4}{|c|}{$\begin{array}{l}\text { Manufacturing, value-added } \\
\text { (\% of GDP) }\end{array}$} & \multicolumn{4}{|c|}{$\begin{array}{l}\text { Agriculture, forestry, ... value-added (\% of } \\
\text { GDP) }\end{array}$} \\
\hline & Mean & Max. & Min. & S.Dev. & Mean & Max. & Min. & S.Dev. & Mean & Max. & Min. & S.Dev. \\
\hline Algeria & 6.528 & 11.258 & 1.307 & 3.992 & 35.353 & 47.325 & 23.836 & 9.722 & 9.856 & 12.38 & 7.834 & 1.827 \\
\hline Benin & 13.669 & 24.55 & 7.282 & 7.681 & 12.143 & 15.676 & 9.574 & 2.519 & 26.436 & 28.11 & 24.962 & 1.024 \\
\hline Botswana & 1.467 & 3.84 & 0.238 & 1.345 & 5.616 & 6.112 & 5.152 & 0.401 & 2.268 & 2.579 & 1.949 & 0.281 \\
\hline Burkina Faso & 5.748 & 8.14 & 2.352 & 2.323 & 12.246 & 15.127 & 10.113 & 2.021 & 23.514 & 26.418 & 20.174 & 2.065 \\
\hline Burundi & 7.387 & 13.277 & 2.604 & 4.322 & 9.886 & 11.234 & 9.104 & 0.912 & 35.877 & 43.339 & 28.898 & 5.37 \\
\hline Cameroon & 10.598 & 16.436 & 3.901 & 5.249 & 14.955 & 17.801 & 12.731 & 1.55 & 14.458 & 16.596 & 13.311 & 1.036 \\
\hline Egypt & 7.296 & 11.527 & 3.66 & 3.099 & 16.421 & 17.639 & 15.559 & 0.681 & 16.421 & 17.639 & 15.559 & 0.681 \\
\hline Eswatini & 2.64 & 3.429 & 2.035 & .529 & 32.122 & 34.868 & 29.665 & 2.121 & 9.946 & 12.329 & 8.455 & 1.304 \\
\hline Ethiopia & 20.761 & 29.583 & 8.954 & 8.194 & 4.875 & 5.902 & 3.692 & 0.909 & 38.906 & 44.444 & 33.197 & 4.243 \\
\hline Gambia, The & 8.436 & 10.733 & 5.026 & 2.038 & 5.485 & 6.523 & 3.967 & 0.891 & 25.684 & 29.93 & 20.912 & 3.736 \\
\hline Ghana & 9.968 & 17.291 & 3.991 & 4.782 & 9.206 & 11.48 & 6.158 & 1.857 & 25.923 & 35.645 & 17.306 & 7.435 \\
\hline Kenya & 9.044 & 16.886 & 1.666 & 6.14 & 10.057 & 12.282 & 7.542 & 1.675 & 27.58 & 34.15 & 22.048 & 4.663 \\
\hline Malawi & 6.585 & 10.953 & 4.283 & 2.173 & 10.518 & 12.128 & 9.404 & 1.25 & 29.679 & 36.775 & 25.541 & 3.932 \\
\hline Mauritania & 13.112 & 22.665 & 1.359 & 8.855 & 7.996 & 10.868 & 6.323 & 1.634 & 19.564 & 24.426 & 15.778 & 2.653 \\
\hline Mauritius & 9.297 & 12.933 & 4.616 & 3.304 & 14.461 & 19.045 & 10.951 & 2.806 & 3.931 & 5.506 & 2.897 & 1.015 \\
\hline Morocco & 4.838 & 6.8 & 1.997 & 1.667 & 15.903 & 17.07 & 14.918 & 0.827 & 12.566 & 13.439 & 11.95 & 0.514 \\
\hline Mozambique & 5.206 & 9.192 & 1.489 & 2.916 & 10.709 & 14.198 & 8.135 & 2.526 & 24.232 & 26.027 & 21.251 & 1.803 \\
\hline Namibia & 2.133 & 12.657 & 0.595 & 3.155 & 11.632 & 12.774 & 10.382 & 0.948 & 8.143 & 10.208 & 6.613 & 1.441 \\
\hline Niger & 7.371 & 13.591 & 2.849 & 3.73 & 7.787 & 8.92 & 7.038 & 0.759 & 36.865 & 40.915 & 32.689 & 2.73 \\
\hline Nigeria & 12.733 & 23.287 & 5.03 & 6.482 & 9.67 & 12.599 & 7.149 & 1.885 & 24.197 & 31.756 & 20.46 & 3.959 \\
\hline Rwanda & 9.043 & 14.733 & 2.616 & 5.002 & 8.165 & 9.286 & 6.873 & 0.838 & 26.772 & 32.57 & 23.547 & 3.719 \\
\hline Senegal & 5.577 & 9.31 & 1.981 & 2.694 & 16.796 & 17.723 & 15.658 & 0.798 & 14.363 & 15.025 & 13.751 & 0.515 \\
\hline South Africa & 10.581 & 14.575 & 3.774 & 4.143 & 13.632 & 17.522 & 11.781 & 2.302 & 2.427 & 3.218 & 1.885 & 0.441 \\
\hline Togo & 10.653 & 16.047 & 2.396 & 4.535 & 7.214 & 7.881 & 6.34 & 0.609 & 29.677 & 33.768 & 22.546 & 4.749 \\
\hline Tunisia & 3.527 & 5.719 & .973 & 1.882 & 15.883 & 17.191 & 14.751 & 0.832 & 9.256 & 10.375 & 8.264 & 0.765 \\
\hline Uganda & 7.944 & 12.394 & 3.046 & 3.723 & 12.653 & 16.896 & 6.822 & 4.422 & 25.054 & 29.437 & 23.052 & 2.23 \\
\hline Zimbabwe & 3.849 & 5.029 & 1.487 & 1.186 & 12.474 & 15.029 & 10.808 & 1.699 & 11.806 & 18.147 & 8.058 & 4.529 \\
\hline
\end{tabular}


Meanwhile, evidence from the table further suggests that countries with a high trading ratio with China tend to have higher agricultural sector value-added to GDP ratio compared with their counterparts with less trade with China. For instance, Ethiopia, which has the largest agricultural sector value-added to the GDP ratio of 38.9 percent is the largest African trading partner with China. The growth in its agricultural sector may not be unrelated to the country's trade with China. Similarly, Benin, Nigeria, and Mauritania, which are among the top African trading partners with China, also have relatively high value-added in the agricultural sector; about 26.4 percent, 24.2 percent, and 19.6 percent agricultural value-added to GDP ratio, respectively. This suggests that China-Africa trade may not be entirely bad for the agricultural sector in Africa. In other words, China-Africa trade may not cause Dutch disease in the agricultural sector in Africa.

Table 4 for the panel descriptive statistics reveals that for the study period, the highest recorded China-Africa trade (as a percentage of total trade) was circa 30\% while the lowest was less than $1 \%$. The average China-Africa trade for the study period was approximately 8\%. Also, for the period under the study, the greatest recorded contribution of the manufacturing sector to the GDP was about 50\% while the lowest was approximately $4 \%$. Manufacturing contribution averaged circa $13 \%$ for our sampled countries. In terms of the contribution of agriculture to the GDP, the highest and lowest recorded values respectively were approximately $44 \%$ and $2 \%$. Agricultural contribution to GDP in our sampled countries was about 20\%. This supports the notion that African countries are industrially less-developed given their greater dependence on the primary sector as compared to the secondary sector. The fact that African countries are less-industrialized is further supported by the fact that agriculture remains the largest employer of labour in our sampled African countries as Table 4 clearly shows. The average percentage of total employment in the agricultural sector is more than double that of total employment in the manufacturing sector. While on average, about $45 \%$ of total employment in our sampled countries is generated from the agricultural sector, just about $16 \%$ of total employment comes from the industrial sector. The highest recorded industrial employment rate (as a percentage of total employment) was approximately $36 \%$ compared to an impressive $92 \%$ agricultural employment (as a percentage of the total employment).

Table-4. Panel descriptive statistics for relevant variables.

\begin{tabular}{|c|c|c|c|c|}
\hline Variable & Mean & Std. Dev. & Min. & Max. \\
\hline China-Africa trade (\% of Total Trade) & 8.094 & 5.740 & 0.238 & 29.58 \\
\hline Manufacturing, value added (\% of GDP) & 12.74 & 7.241 & 3.692 & 47.32 \\
\hline $\begin{array}{l}\text { Agriculture, forestry, and fishing, value added (\% of } \\
\text { GDP) }\end{array}$ & 19.69 & 10.87 & 1.885 & 44.44 \\
\hline $\begin{array}{l}\text { Employment in agriculture (\% of total employment) } \\
\text { (modeled ILO estimate) }\end{array}$ & 44.68 & 23.68 & 4.765 & 92.28 \\
\hline $\begin{array}{l}\text { Employment in industry (\% of total employment) } \\
\text { (modeled ILO estimate) }\end{array}$ & 15.65 & 8.420 & 1.465 & 35.75 \\
\hline $\begin{array}{l}\text { Foreign direct investment, net inflows (BoP, current } \\
\mathrm{US} \$ \text { ) }\end{array}$ & $1.122 \mathrm{e}+09$ & $1.777 \mathrm{e}+09$ & $-8.836 \mathrm{e}+08$ & $9.261 \mathrm{e}+09$ \\
\hline Trade $(\%$ of GDP $)$ & 65.48 & 25.21 & 23.34 & 168.0 \\
\hline Official exchange rate (LCU per US\$, period average) & 305.7 & 489.0 & 0.269 & 2,556 \\
\hline Personal remittances, received (\% of GDP) & 3.095 & 3.079 & 0.00396 & 15.09 \\
\hline GDP per capita (constant $2010 \mathrm{US} \$$ ) & 2,309 & 2,327 & 202.5 & 10,893 \\
\hline Broad money (\% of GDP) & 41.97 & 28.13 & 8.170 & 163.3 \\
\hline Infrastructure index & 25.04 & 19.46 & 0.369 & 87.23 \\
\hline
\end{tabular}

\subsection{Econometric Analysis}

This section provides an econometric analysis on the effect of China-Africa trade on Africa's manufacturing and agricultural sectors using two-step Difference and System General Method of Moments (GMM). The use of GMM allows us to account for persistence and endogeneity in modelling the determinants of growth in the manufacturing and agricultural sectors in Africa. Meanwhile, we also employ the dynamic least square regression as well as dynamic fixed and random effect models for robustness. While GMM captures both persistence and endogeneity, 
dynamic pooled OLS and dynamic fixed and random effect models only capture persistence with their lagged dependent variable.

Table 5 reports empirical results in respect of China-Africa trade and Africa's manufacturing sector performance. The model diagnostics for the two-step difference GMM (DGMM2) and the two-step system GMM (SGMM2) revealed that the models are efficient and the results are reliable. The Hansen and Sargan tests for the validity of the instrumental variables show that the null hypothesis that the instruments are valid cannot be rejected.

This suggests that these models carefully take care of the potential endogeneity bias in the model. As expected, the $\operatorname{AR}(1)$ statistic is statistically significant under the two dynamic models and the $\operatorname{AR}(2)$ is not statistically significant. This suggests that our GMM models capture potential higher-order autocorrelation as expected. On the dynamic POLS, FE, and RE models, the chi-square for the test of fixed effect shows that the null hypothesis of a common constant parameter is rejected; implying the existence of a fixed effect. The Hausman test statistic is also statistically significant, suggesting a preference for the dynamic FE model over dynamic POLS and RE models.

Table-5. Results for China-Africa trade and Africa's Manufacturing sector performance.

\begin{tabular}{|c|c|c|c|c|c|}
\hline Statistics & SYS-GMM2 & DIFF-GMM2 & OLS & FE & RE \\
\hline \multirow[t]{2}{*}{ L.lman } & $0.946^{* * * *}$ & $0.733^{* * *}$ & $0.968^{* * *} *$ & $0.804^{* * * *}$ & $0.968^{* * * *}$ \\
\hline & $(0.0421)$ & $(0.253)$ & $(0.0108)$ & $(0.0285)$ & $(0.0108)$ \\
\hline \multirow[t]{2}{*}{ lempman } & 0.00183 & -0.0725 & -0.00165 & -0.00648 & -0.00165 \\
\hline & $(0.00864)$ & (0.197) & $(0.0104)$ & $(0.0344)$ & $(0.0104)$ \\
\hline \multirow[t]{2}{*}{ linfr } & 0.0136 & -0.0721 & 0.00722 & -0.0206 & 0.00722 \\
\hline & $(0.00930)$ & $(0.0608)$ & $(0.00833)$ & $(0.0237)$ & $(0.00833)$ \\
\hline \multirow[t]{2}{*}{ lchnafrtrade } & -0.00430 & 0.00159 & -0.00128 & -0.00570 & -0.00128 \\
\hline & $(0.00835)$ & $(0.00885)$ & $(0.00507)$ & $(0.00708)$ & $(0.00507)$ \\
\hline \multirow[t]{2}{*}{ lexr } & 0.00328 & 0.0223 & 0.00163 & 0.00287 & 0.00163 \\
\hline & $(0.00343)$ & $(0.0138)$ & $(0.00269)$ & $(0.0104)$ & $(0.00269)$ \\
\hline \multirow[t]{2}{*}{$\operatorname{lgdp}$} & 0.00507 & -0.000526 & 0.00470 & 0.0352 & 0.00470 \\
\hline & $(0.00836)$ & $(0.260)$ & $(0.00886)$ & $(0.0562)$ & $(0.00886)$ \\
\hline \multirow[t]{2}{*}{ Ltop } & -0.000312 & -0.0210 & -0.00153 & -0.0315 & -0.00153 \\
\hline & $(0.0148)$ & $(0.102)$ & $(0.0143)$ & $(0.0277)$ & $(0.0143)$ \\
\hline \multirow[t]{2}{*}{ Constant } & 0.0341 & & 0.0187 & 0.415 & 0.0187 \\
\hline & $(0.0893)$ & & $(0.0684)$ & $(0.370)$ & $(0.0684)$ \\
\hline \multicolumn{6}{|c|}{ Model Diagnostics } \\
\hline Hansen test & $\begin{array}{c}2.141 \\
{[0.829]}\end{array}$ & $\begin{array}{c}1.718 \\
{[0.787]}\end{array}$ & - & - & - \\
\hline Sargan test & $\begin{array}{c}2.415 \\
{[0.789]}\end{array}$ & $\begin{array}{c}0.983 \\
{[0.912]}\end{array}$ & - & - & - \\
\hline $\operatorname{AR}(1)$ & $\left.\begin{array}{c}-2.729 \\
{[0.00636}\end{array}\right]$ & $\begin{array}{c}-1.881 \\
{[0.0599]}\end{array}$ & - & - & - \\
\hline $\operatorname{AR}(2)$ & $\begin{array}{l}-1.417 \\
{[0.156]}\end{array}$ & $\begin{array}{l}-1.342 \\
{[0.180]}\end{array}$ & - & - & - \\
\hline No. of Instr. & 13 & 11 & - & - & - \\
\hline F-test (u_i) & - & - & - & $\begin{array}{l}1.98 * * * \\
{[0.0032]}\end{array}$ & - \\
\hline Hausman & - & - & - & - & $\begin{array}{l}41.11^{* * * *} \\
{[0.0000]}\end{array}$ \\
\hline Countries & 27 & 27 & 27 & 27 & 27 \\
\hline Obs. & 486 & 459 & 486 & 486 & 486 \\
\hline
\end{tabular}

Note: ****** and * indicate statistical significance at $1 \%, 5 \%$ and $10 \%$ significance level, respectively. Figures in the round bracket represent standard errors, while figures in square brackets indicate probability values.

Empirically, the result in Table 5 shows that growth in Africa's manufacturing sector is mainly determined by past development within the sector; as there is positive persistence in the manufacturing value-added process.

Thus, to achieve enhanced development in the manufacturing sector in Africa, a long-term development policy on the promotion of the manufacturing sector would be required. This may be in the form of diversification into the 
sector, where large initial capital would be invested in the sector. This appears to be the only factor that could stimulate significant growth in Africa's manufacturing sector, as other relevant determinants such as employment within the sector, infrastructure, exchange rate, trade openness, and income level do not stimulate significant development in the sector.

Table-6. Results for China-Africa trade and Africa's Agricultural sector performance.

\begin{tabular}{|c|c|c|c|c|c|}
\hline Statistics & SYS-GMM2 & DIFF-GMM2 & OLS & FE & RE \\
\hline \multirow[t]{2}{*}{ L.lagr } & $0.694^{* * * *}$ & $-1.942^{*} * *$ & $0.973^{* * * *}$ & $0.745^{* * * *}$ & $0.973^{* * *}$ \\
\hline & $(0.130)$ & $(0.610)$ & $(0.0124)$ & $(0.0322)$ & $(0.0124)$ \\
\hline \multirow[t]{2}{*}{ lempagr } & 0.0493 & -0.564 & 0.00761 & 0.0199 & 0.00761 \\
\hline & $(0.0837)$ & $(3.098)$ & $(0.0120)$ & $(0.0383)$ & $(0.0120)$ \\
\hline \multirow[t]{2}{*}{ linfr } & -0.0180 & -0.727 & -0.00377 & $0.0470^{* * *}$ & -0.00377 \\
\hline & (0.0359) & $(1.175)$ & (0.00830) & (0.0229) & $(0.00830)$ \\
\hline \multirow[t]{2}{*}{ lchnafrtrade } & 0.0240 & 0.00912 & 0.00593 & 0.00676 & 0.00593 \\
\hline & $(0.0153)$ & $(0.0114)$ & $(0.00498)$ & $(0.00676)$ & $(0.00498)$ \\
\hline \multirow[t]{2}{*}{ lexr } & 0.00414 & $0.105^{*}$ & -0.000651 & $-0.0244^{* *}$ & -0.000651 \\
\hline & (0.0109) & $(0.0625)$ & $(0.00255)$ & $(0.0100)$ & $(0.00255)$ \\
\hline \multirow[t]{2}{*}{$\operatorname{lgdp}$} & $-0.162^{*}$ & -0.409 & -0.0114 & $-0.180^{* * * *}$ & -0.0114 \\
\hline & $(0.0923)$ & $(0.428)$ & $(0.0111)$ & $(0.0550)$ & $(0.0111)$ \\
\hline \multirow[t]{2}{*}{ ltop } & -0.0333 & -0.0844 & -0.0112 & 0.000209 & -0.0112 \\
\hline & $(0.0627)$ & $(0.0679)$ & (0.0139) & $(0.0244)$ & (0.0139) \\
\hline \multirow[t]{2}{*}{ Constant } & $1.939 *$ & & 0.165 & 1.877 *** & 0.165 \\
\hline & $(1.044)$ & & $(0.136)$ & $(0.461)$ & $(0.136)$ \\
\hline \multicolumn{6}{|c|}{ Model Diagnostics } \\
\hline Hansen test & $\begin{array}{c}5.727 \\
{[0.220]}\end{array}$ & $\begin{array}{c}2.048 \\
{[0.359]}\end{array}$ & - & - & - \\
\hline Sargan test & $\begin{array}{c}6.333 \\
{[0.176]}\end{array}$ & $\begin{array}{c}1.948 \\
{[0.378]}\end{array}$ & - & - & - \\
\hline $\operatorname{AR}(1)$ & $\begin{array}{c}-3.055 \\
0.00225]\end{array}$ & $\begin{array}{c}1.912 \\
{[0.0559]}\end{array}$ & - & - & - \\
\hline $\operatorname{AR}(2)$ & $\begin{array}{l}-1.639 \\
{[0.101]}\end{array}$ & $\begin{array}{l}-1.299 \\
{[0.194]}\end{array}$ & - & - & - \\
\hline No. of Instr. & 12 & 9 & - & - & - \\
\hline F-test (u_i) & - & - & - & $\begin{array}{l}2.83^{* * * *} \\
{[0.0000]}\end{array}$ & - \\
\hline Hausman & - & - & - & - & $\begin{array}{l}66.30 * * * \\
{[0.0000]}\end{array}$ \\
\hline Countries & 27 & 27 & 27 & 27 & 27 \\
\hline Obs. & 486 & 459 & 486 & 486 & 486 \\
\hline
\end{tabular}

Note: ****** and * indicate statistical significance at $1 \%, 5 \%$ and $10 \%$ significance level, respectively. Figures in round bracket represent standard errors, while figures in square brackets indicate probability values.

As regards the China-Africa trade, the result from the two-step system GMM (SGMM2) model reveals evidence of a negative (though not significant) relationship between China-Africa trade and manufacturing sector productivity. This result is confirmed by all the alternative models; dynamic OLS, FE, and RE models, except the DGMM2 model.

This may suggest that the relationship is better explained by the system GMM. The existence of a negative, insignificant relationship between China-Africa and manufacturing sector productivity of African countries implies that higher trade intensity between China and Africa has the potential to reduce Africa's manufacturing valueadded. In other words, although China-Africa trade is not causing a reduction in manufacturing sector productivity at present, it has the chance of reducing it in the future.

By implication, our result suggests that the China-Africa trade does not cause Dutch disease in Africa but has the potential to cause Dutch disease in the future. This finding is supported by the work of Huang et al. (2017) and Davies et al. (2014) where it was reported that China-Africa trade may retard the development of local industry in 
Africa. Davies et al. (2014) in their study stated that China's policy to provide economic and technological aids in exchange for natural resources from Africa undermines African industry because of Chinese exports.

The results of the relationship between China-Africa trade and agricultural sector productivity are presented in Table 6. As in the results of the relationship between China-Africa trade and manufacturing sector productivity, the Sargan and Hansen tests statistic are not statistically significant, implying that the instruments used for the GMM modelling are valid.

Also, as expected, the AR (1) autocorrelation statistics for the two GMM models are not significant but the $\operatorname{AR}(2)$ autocorrelation statistic is significant for the models. This is an indication that the GMM models suffer no higher-order autocorrelation. The chi-square test results and the Hausman test also favour the dynamic fixed effect model as against the dynamic POLS and dynamic RE models.

Similarly, the result in Table 6 shows that growth in Africa's agricultural sector is also largely driven by developments within the sector. This is explained by the evidence of positive persistence in the agricultural sector productivity.

This implies that a long-term development policy with large initial capital would also help to stimulate significant growth in Africa's agricultural sector. Aside from the persistence effect, income (lgdp) has a negative and statistically significant effect on agricultural sector productivity. Trade openness, infrastructure, employment in the agricultural sector, and exchange rate do not seem to have a significant impact on agricultural sector productivity. Meanwhile, the constant term in the SGMM2 model is statistically significant, suggesting that the level equation is important, and the difference GMM is not appropriate. This suggests that the SGMM model is preferred in this case.

On the effect of China-Africa trade on Africa's agricultural sector productivity, the result from the two-step system GMM (SGMM2) model reveals evidence of a positive (though not significant) relationship between ChinaAfrica trade and Africa's agricultural sector productivity. This result is confirmed by all the alternative models; DGMM2 model, dynamic OLS, FE, and RE models. The existence of a positive, insignificant relationship between China-Africa and agricultural sector productivity of African countries implies that higher trade intensity between China and Africa has the potential to increase Africa's agricultural productivity.

Thus, although China-Africa trade is not significantly promoting Africa's agricultural sector productivity at present, it has the chance of increase the sector's productivity in the future. By implication, our result suggests that China-Africa trade has no tendency of causing agricultural-sector-related Dutch disease. Our findings are in line with Buckley, Chen, Yin, and Zhu (2017) but differ from that of Apergis et al. (2014). Buckley et al. (2017) noted that the Chinese are increasingly engaging in African agriculture in the form of direct agriculture-technology transfer, support is also provided for agricultural vocational education for Africans, including agriculture education and training programmes for African stakeholders in both China and Africa.

\subsection{Robustness Checks}

For robustness purposes, this study further employed an analysis that utilizes 3 years average point data set to investigate the Dutch diseases implication for China-Africa trade relations for Africa. The results of the analysis using DIFF-GMM and SYS-GMM, as well as the dynamic pooled OLS, the random (RE) and Fixed effect (FE) models are presented in Table 7 for the effect of China-Africa trade on Africa's manufacturing sector performance and in Table 8 for the effect of China-Africa trade on Africa's agricultural sector productivity.

As evident from Tables 7 and 8, the model diagnostics for the efficiency of the dynamics models are satisfied; judging by the Sargan and Hansen statistics as well as the $\operatorname{AR}(1)$ and $\operatorname{AR}(2)$ statistics. The fixed effect chi-square and the Hausman test statistics are also in support of the fixed-effect model. In Table 7, we can observe that Africa's manufacturing sector productivity is mainly explained by past development within the sector, while the effect of China-Africa trade on the sector's performance in Africa is negative but not statistically significant. Just like under 
the main model, this result is confirmed by all the alternative models except the Difference GMM models. This suggests that DGMM2 is not an appropriate model for modelling the relationship between China-Africa trade and Africa's manufacturing sector productivity. Thus, our result that China-Africa trade is not causing Dutch disease in Africa but has the potential to cause Dutch disease in the future, is robust to a different data structure for the dynamic GMM model.

Table-7. Results for China-Africa trade and Africa's Manufacturing sector performance (3-year average).

\begin{tabular}{|c|c|c|c|c|c|}
\hline Statistics & SYS-GMM2 & DIFF-GMM2 & OLS & $\mathbf{F E}$ & $\mathbf{R E}$ \\
\hline \multirow[t]{2}{*}{ L.lman } & $0.690^{*} * *$ & $0.994 * * *$ & $0.932^{* * * *}$ & $0.599^{* * * *}$ & $0.932^{* * * *}$ \\
\hline & $(0.123)$ & $(0.302)$ & $(0.0257)$ & $(0.0691)$ & $(0.0257)$ \\
\hline \multirow[t]{2}{*}{ lempman } & 0.0322 & 0.102 & -0.00446 & 0.108 & -0.00446 \\
\hline & $(0.0415)$ & $(0.149)$ & $(0.0245)$ & $(0.0931)$ & $(0.0245)$ \\
\hline \multirow[t]{2}{*}{ linfr } & 0.0628 & -0.109 & 0.0231 & 0.00332 & 0.0231 \\
\hline & $(0.0416)$ & $(0.0881)$ & $(0.0218)$ & $(0.0695)$ & $(0.0218)$ \\
\hline \multirow[t]{2}{*}{ lchnafrtrade } & -0.0464 & 0.0147 & -0.0126 & -0.0417 & -0.0126 \\
\hline & $(0.0502)$ & $(0.0373)$ & $(0.0163)$ & $(0.0284)$ & (0.0163) \\
\hline \multirow[t]{2}{*}{ lexr } & $0.0248 * *$ & 0.149 & 0.00410 & 0.0464 & 0.00410 \\
\hline & $(0.0110)$ & $(0.0927)$ & $(0.00665)$ & $(0.0872)$ & $(0.00665)$ \\
\hline \multirow[t]{2}{*}{$\operatorname{lgdp}$} & 0.0403 & 0.167 & 0.00900 & -0.0185 & 0.00900 \\
\hline & $(0.0464)$ & $(0.207)$ & $(0.0204)$ & $(0.147)$ & $(0.0204)$ \\
\hline \multirow[t]{2}{*}{ ltop } & -0.0371 & -0.0898 & -0.0210 & -0.0966 & -0.0210 \\
\hline & $(0.0423)$ & $(0.0757)$ & (0.0349) & $(0.0732)$ & (0.0349) \\
\hline \multirow[t]{2}{*}{ Constant } & 0.292 & & 0.106 & 1.076 & 0.106 \\
\hline & $(0.332)$ & & $(0.177)$ & $(0.939)$ & $(0.177)$ \\
\hline \multicolumn{6}{|c|}{ Model Diagnostics } \\
\hline Hansen test & $\begin{array}{c}3.228 \\
{[0.665]}\end{array}$ & $\begin{array}{c}3.423 \\
{[0.331]}\end{array}$ & - & - & - \\
\hline Sargan test & $\begin{array}{c}4.639 \\
{[0.461]}\end{array}$ & $\begin{array}{c}2.746 \\
{[0.432]}\end{array}$ & - & - & - \\
\hline $\operatorname{AR}(1)$ & $\begin{array}{c}-1.963 \\
{[0.0496]}\end{array}$ & $\begin{array}{c}-1.701 \\
{[0.0889]}\end{array}$ & - & - & - \\
\hline $\operatorname{AR}(2)$ & $\begin{array}{l}-1.117 \\
{[0.264]}\end{array}$ & $\begin{array}{c}-1.008 \\
{[0.313]}\end{array}$ & - & - & - \\
\hline No. of Instr. & 13 & 10 & - & - & - \\
\hline F-test (u_i) & - & - & - & $\begin{array}{l}2.02^{* * * *} \\
{[0.0056]}\end{array}$ & - \\
\hline Hausman & - & - & - & - & $\begin{array}{l}36.53^{* * * *} \\
{[0.0000]}\end{array}$ \\
\hline Countries & 27 & 27 & 27 & 27 & 27 \\
\hline Obs. & 162 & 135 & 162 & 162 & 162 \\
\hline
\end{tabular}

Note: ****** and * indicate statistical significance at $1 \%, 5 \%$ and $10 \%$ significance level, respectively. Figures in the round bracket represent standard errors, while figures in the square brackets indicate probability values.

On the other hand, in Table 7, we can observe that Africa's agricultural sector productivity is significantly explained by past development within the sector, which is consistent with the main results.

The effect of China-Africa trade on Africa's agricultural sector productivity, however, turned to be statistically significant; at 10\% under the system GMM, which is confirmed by the fixed effect model. This suggests that the potential of China-Africa trade to contribute significantly to the development of Africa's agricultural sector productivity can be sooner than later. Thus, our result that China-Africa trade has no tendency of causing agricultural-sector-related Dutch disease is robust to a different data structure for the dynamic GMM model.

\section{CONCLUSION}

This study revisits the analysis of the implication of China-Africa trade for Africa's non-mineral resources sectors. It contributes to the literature on the implication of China-Africa trade in two distinct ways. Empirically, we measure the performance of Africa's non-mineral resources sector using sectoral value-added (as a percentage of 
GDP) as against other measures used in the earlier studies such as sectoral export and export diversification index, which focus only on export potential and ignore possible extension in sectoral production that only increases the domestic absorptive level without leading to export.

The measure employed captures all output but the sector and avoids the possible problem of under-valuation or under-estimation of sectoral performance. Also, while previous studies focus on the manufacturing sector to examine trade implications of a Dutch disease syndrome, we focus on both manufacturing and agricultural sectors, as recent studies suggest that trade could also cause neglect of the agricultural sector, thus having Dutch disease implications.

Table-8. Results for China-Africa trade and Africa's Agricultural sector performance (3-year average)

\begin{tabular}{|c|c|c|c|c|c|}
\hline Statistics & SYS-GMM2 & DIFF-GMM2 & OLS & FE & $\mathbf{R E}$ \\
\hline \multirow[t]{2}{*}{ L.lagr } & $0.807^{* * * *}$ & $-0.479^{*}$ & $0.968^{* * * *}$ & $0.660^{* * * *}$ & $0.949^{* * * *}$ \\
\hline & $(0.163)$ & $(0.288)$ & $(0.0257)$ & $(0.0687)$ & $(0.0291)$ \\
\hline \multirow[t]{2}{*}{ lempagr } & 0.0105 & 0.125 & 0.0109 & -0.0347 & 0.0128 \\
\hline & $(0.0513)$ & $(0.174)$ & $(0.0243)$ & $(0.0832)$ & $(0.0280)$ \\
\hline \multirow[t]{2}{*}{ Linfr } & -0.0212 & 0.0784 & -0.00134 & 0.0866 & -0.00264 \\
\hline & $(0.0359)$ & $(0.152)$ & $(0.0189)$ & $(0.0574)$ & (0.0213) \\
\hline \multirow[t]{2}{*}{ lchnafrtrade } & $0.0462 *$ & -0.0353 & 0.0222 & $0.0477 * *$ & $0.0305 * *$ \\
\hline & $(0.0264)$ & $(0.0367)$ & $(0.0141)$ & $(0.0232)$ & $(0.0149)$ \\
\hline \multirow[t]{2}{*}{ lexr } & -0.00635 & -0.0322 & -0.000116 & $-0.135^{*}$ & -0.00131 \\
\hline & $(0.00853)$ & $(0.0941)$ & $(0.00540)$ & (0.0696) & $(0.00629)$ \\
\hline \multirow[t]{2}{*}{$\operatorname{lgdp}$} & -0.0960 & $-0.720^{*}$ & -0.0144 & $-0.313^{* * *} *$ & -0.0249 \\
\hline & $(0.0923)$ & $(0.399)$ & $(0.0222)$ & $(0.114)$ & $(0.0257)$ \\
\hline \multirow[t]{2}{*}{ ltop } & -0.0521 & 0.0550 & -0.0146 & -0.0333 & -0.0187 \\
\hline & $(0.0529)$ & $(0.121)$ & $(0.0292)$ & $(0.0541)$ & $(0.0323)$ \\
\hline \multirow[t]{2}{*}{ Constant } & 1.376 & & 0.138 & $3.659^{* * * *}$ & 0.271 \\
\hline & $(1.413)$ & & $(0.283)$ & $(0.938)$ & $(0.321)$ \\
\hline \multicolumn{6}{|c|}{ Model Diagnostics } \\
\hline Hansen test & $\begin{array}{c}2.632 \\
{[0.452]}\end{array}$ & $\begin{array}{c}2.725 \\
{[0.436]}\end{array}$ & - & - & - \\
\hline Sargan test & $\begin{array}{c}1.885 \\
{[0.597]}\end{array}$ & $\begin{array}{c}1.021 \\
{[0.796]}\end{array}$ & - & - & - \\
\hline $\operatorname{AR}(1)$ & $\begin{array}{c}-2.241 \\
{[0.0250]}\end{array}$ & $\begin{array}{c}1.718 \\
{[0.0857]}\end{array}$ & - & - & - \\
\hline $\operatorname{AR}(2)$ & $\begin{array}{l}-1.619 \\
{[0.105]}\end{array}$ & $\begin{array}{c}0.247 \\
{[0.805]}\end{array}$ & - & - & - \\
\hline No. of Instr. & 11 & 10 & - & - & - \\
\hline F-test (u_i) & - & - & - & $\begin{array}{c}2.69^{* * * *} \\
{[0.0001]}\end{array}$ & - \\
\hline Hausman & - & - & - & - & $\begin{array}{l}44.78 * * * \\
{[0.0000]}\end{array}$ \\
\hline Countries & 27 & 27 & 27 & 27 & 27 \\
\hline Obs. & 162 & 135 & 162 & 162 & 162 \\
\hline
\end{tabular}

Note: ****** and * indicate statistical significance at $1 \%, 5 \%$ and $10 \%$ significance level, respectively. Figures in the round bracket represent standard errors, while figures in square brackets indicate probability values.

In terms of methodology, this study employs the two-step dynamic (difference and system) Generalized Method of Moments (GMM) by Arellano and Bond (1991) and Blundell and Bond (1998). This method is more efficient in dealing with short panels; where there is an asymptotic of large $\mathrm{N}$ and small $\mathrm{T}$ (which is the case in this study) (Blackburne \& Frank, 2007). The significance of the two-step dynamic GMM model in dealing with endogeneity and heterogeneity issues has been well appreciated in studies on Dutch disease analysis (see (Apergis et al., 2014; Habiyaremye, 2016; Matallah, 2020)) albeit not on Dutch disease analysis of China-Africa trade on African countries. This study will fill an important gap in the literature as it sets to be the first study on the effect of ChinaAfrica trade on African sectoral performance to employ dynamic (difference and system) Generalized Method of Moments (GMM) models. 
We conduct extensive trend analysis and descriptive statistics, which describe China-Africa's trade patterns and the performance of the manufacturing and agricultural sectors for Africa as a whole and for the specific countries. We observe that countries with a fast-growing manufacturing sector in Africa have a low trade ratio with China, and countries with a low manufacturing sector have a high trade ratio with China, which indicates the possible presence of Dutch disease.

On the other hand, we notice countries with a high trading ratio with China tend to have a higher agricultural sector value-added to GDP ratio compared with their counterparts with less trade with China. This suggests that China-Africa trade may not be entirely bad for the agricultural sector in Africa. In other words, the China-Africa trade may not cause Dutch disease in the agricultural sector in Africa.

We employ a two-step system and difference GMM models as well as dynamic POLS, FE, and RE effect models to assess the consistency of our results. We also employ a 3-year average dataset, which reduced our time observation from nineteen (19) to seven (7). Two-step system GMM (SGMM2) outperforms two-step difference GMM (DGMM2) consistently among the GMM models, and its result is corroborated with the result of the dynamic FE model, which also outperforms other dynamic least square models consistently. Empirical results from this study revealed evidence of a negative (though not significant) relationship between China-Africa trade and manufacturing sector productivity.

This implies that a higher trade size between China and Africa has the potential to reduce Africa's manufacturing value-added. By implication, our result suggests that the China-Africa trade is not causing Dutch disease in Africa but has the potential to cause Dutch disease in the future. For the agricultural sector, however, we find evidence of a positive (though not significant) relationship between China-Africa trade and Africa's agricultural sector productivity. The existence of a positive, insignificant relationship between China-Africa and agricultural sector productivity of African countries implies that higher trade intensity between China and Africa has the potential to increase Africa's agricultural productivity. By implication, our result suggests that China-Africa trade has no tendency of causing Dutch disease in the agricultural sector. Our results are robust to a different data structure for the dynamic GMM model.

Funding: This study received no specific financial support.

Competing Interests: The authors declare that they have no competing interests.

Acknowledgement: All authors contributed equally to the conception and design of the study.

\section{REFERENCES}

Ado, A., \& Su, Z. (2016). China in Africa: A critical literature review. Critical Perspectives on International Business, 12(1), 40-60. Available at: https://doi.org/10.1108/cpoib-05-2013-0014.

Alsharif, N., Bhattacharyya, S., \& Intartaglia, M. (2017). Economic diversification in resource rich countries: History, state of knowledge and research agenda. Resources Policy, 52, 154-164. Available at: https://doi.org/10.1016/j.resourpol.2017.02.007.

Apergis, N., El-Montasser, G., Sekyere, E., Ajmi, A. N., \& Gupta, R. (2014). Dutch disease effect of oil rents on agriculture value added in Middle East and North African (MENA) countries. Energy Economics, 45, 485-490. Available at: https://doi.org/10.1016/j.eneco.2014.07.025.

Arellano, M., \& Bond, S. (1991). Some tests of specification for panel data: Monte Carlo evidence and an application to employment equation. Review of Economic Studies, 58, 277-297. Available at: https://doi.org/10.2307/2297968.

Asongu, S. A., \& Aminkeng, G. A. A. (2013). The economic consequences of China-Africa relations: Debunking myths in the debate. Journal of Chinese Economic and Business Studies, 11(4), 261-277. Available at: https://doi.org/10.1080/14765284.2013.838384.

Baltagi, B. H. (2008). Econometric analysis of panel data (6th ed.). Chichester: Wiley. 
Barczikay, T., Biedermann, Z., \& Szalai, L. (2020). An investigation of a partial Dutch disease in Botswana. Resources Policy, 67, 101665. Available at: https://doi.org/10.1016/j.resourpol.2020.101665.

Blackburne, E. F., \& Frank, M. W. (2007). Estimation of nonstationary heterogeneous panels. The Stata Journal, 7(2), $197-208$. Available at: https://doi.org/10.1177/1536867X0700700204.

Blundell, R., \& Bond, S. (1998). Initial conditions and moment restrictions in dynamic panel data models. Journal of Econometrics, 87, 115-143. Available at: https://doi.org/10.1016/S0304-4076(98)00009-8.

Buckley, L., Chen, R., Yin, Y., \& Zhu, Z. (2017). Chinese agriculture in Africa: Perspectives of Chinese agronomists on agricultural aid. International Institute for Environment and Development (IIED) Discussion Paper. Retrieved from: https://pubs.iied.org/sites/default/files/pdfs/migrate/17603IIED.pdf.

Davies, M., Draper, P., \& Edinger, H. (2014). Changing China, changing Africa: Future contours of an emerging relationship. Asian Economic Policy Review, 9(2), 180-197. Available at: https://doi/abs/10.1111/aepr.12059.

De Grauwe, P., Houssa, R., \& Piccillo, G. (2012). African trade dynamics: Is China a different trading partner? Journal of Chinese Economic and Business Studies, 1O(1), 15-45. Available at: https://doi.org/10.1080/14765284.2012.638460.

Eisenman, J. (2012). China-Africa trade patterns: Causes and consequences. Journal of Contemporary China, 21(77), 793-810. Available at: https://doi.org/10.1080/10670564.2012.684964.

Geda, A., Mosisa, S., \& Assefa, M. (2013). To be or not to be: Dilemma of Africa's economic engagement with China and other emerging economies. Africa Review, 5(2), 118-138. Available at: https://doi.org/10.1080/09744053.2013.855357.

Habiyaremye, A. (2016). Is Sino-African trade exacerbating resource dependence in Africa? Structural Change and Economic Dynamics, 37, 1-12. Available at: https://doi.org/10.1016/j.strueco.2015.11.003.

He, Y. (2013). Does China's trade expansion help African development? — an empirical estimation. China Economic Revierw, 26, 28-38. Available at: https://doi.org/10.1016/j.chieco.2013.04.001.

Huang, S., An, H., Viglia, S., Buonocore, E., Fang, W., \& Ulgiati, S. (2017). Revisiting China-Africa trade from an environmental perspective. Journal of Cleaner Production, 167, 553-570. Available at: https://doi.org/10.1016/j.jclepro.2017.08.171.

Kireyev, A. (2021). Diversification in the Middle East: From crude trends to refined policies. The Extractive Industries and Society, 8(2), 100701. Available at: https://doi.org/10.1016/j.exis.2020.03.013.

Martuscelli, A. (2018). The economics of China's engagement with Africa: What is the empirical evidence? Development Policy Review, 38(3), 285-302. Available at: https://doi.org/10.1111/dpr.12456.

Maswana, J. C. (2009). Can China trigger economic growth in Africa? An empirical investigation based on the economic interdependence hypothesis. Chinese Economy, 42(2), 91-105. Available at: https://doi.org/10.2753/CES10971475420205.

Matallah, S. (2020). Economic diversification in MENA oil exporters: Understanding the role of governance. Resources Policy, 66, 101602. Available at: https://doi.org/10.1016/j.resourpol.2020.101602.

Mlambo, C., Kushamba, A., \& Simawu, M. B. (2016). China-Africa relations: What lies beneath? The Chinese Economy, 49(4), 257276. Available at: https://doi.org/10.1080/10971475.2016.1179023.

Nowak, W. (2016). China-Africa and India-Africa trade in the years 2000-2014. Procedia Economics and Finance, 39, $140-146$. Available at: https://doi.org/10.1016/S2212-5671(16)30261-1.

Olubusoye, O. E., Salisu, A. A., \& Olofin, S. O. (2016). Applied panel data analysis. Nigeria: Ibadan University Press.

Peh, K. S. H., \& Eyal, J. (2010). Unveiling China's impact on African environment. Energy Policy, 38, 4729-4730. Available at: https://doi.org/10.1016/j.enpol.2010.02.028.

Rashid, K. H. U., Islam, T., Yousaf, S. U., Zaman, K., Shoukry, A. M., Sharkawy, M. A., \& Hishan, S. S. (2019a). The impact of financial development indicators on natural resource markets: Evidence from two-step GMM estimator. Resources Policy, 62, 240-255. Available at: https://doi.org/10.1016/j.resourpol.2019.04.002.

Rashid, K. H. U., Nassani, A. A., Aldakhil, A. M., Qazi Abro, M. M., Islam, T., \& Zaman, K. (2019b). Pro-poor growth and sustainable development framework: Evidence from two step GMM estimator. Journal of Cleaner Production, 206, 767784. Available at: https://doi.org/10.1016/j.jclepro.2018.09.195. 
Sung, B., Song, W. Y., \& Park, S. D. (2018). How foreign direct investment affects CO 2 emission levels in the Chinese manufacturing industry: Evidence from panel data. Economic Systems, 42(2), 320-331. Available at: https://doi.org/10.1016/j.ecosys.2017.06.002.

Taivan, A., Nene, G., \& Boubacar, I. (2015). Commodity exports to China and economic growth: The case of Sub-Saharan African (SSA) countries. Nankai Business Review International, 6(4), 401-416. Available at: https://doi.org/10.1108/nbri-11-2014-0041.

Tawiah, V., Zakari, A., \& Khan, I. (2020). The environmental footprint of China-Africa engagement: An analysis of the effect of China - Africa partnership on carbon emissions. Science of the Total Environment, 756, 143603. Available at: https://doi.org/10.1016/j.scitotenv.2020.143603.

Views and opinions expressed in this article are the views and opinions of the author(s), Quarterly Journal of Econometrics Research shall not be responsible or answerable for any loss, damage or liability etc. caused in relation to/arising out of the use of the content. 